\title{
VIEWPOINTS
}

\section{Encouragement of Scientific Enquiry in the Noble Qur'an}

\section{Daud AbdulFattah Batchelor*}

For our enlightenment and progress, the Muslim ummah today needs to regain the spirit of wonder of the early Muslims whose faith in God (iman) soared under inspiration from the Qur'anic revelation and tutelage of Prophet Muhammad (peace be upon him). With these, Muslims could appreciate God's Majesty and Omnipotence, and His Mercy and Benevolence in creating the universe with man in the august role as khalifah (vicegerent) and custodian of the earth and the heavens. In one inspiring verse 45:13, God says: "He has subjected to you, as from Him, all that is in the heavens and on earth. Behold! In that are signs indeed for those who reflect."

The imagination of a Muslim scientist reading the Noble Qur'an would thus naturally be stirred by verses where Allah avers to natural phenomena and their benefits, encouraging mankind to investigate more deeply. The Prophet (pbuh) encouraged people to "explore the meanings of the Qur'an and to search for its mysteries". Islam as a science-friendly religion promotes scientific investigation and technological advancement that contributes to human wellbeing.

Muhammad Iqbal wrote in his book, The Reconstruction of Religious Thought in Islam, that for a long time Muslim scholarship remained under the influence of Hellenistic thought that was theory-oriented. The Qur'an however, eventually changed that and in this sense Iqbal characterised the Qur'an as "anticlassical" in its strong focus on experimentation and inductive reasoning. This is a great encouragement for Muslim scientists to seek beneficial knowledge. Consequently, early Muslim scientists expanded the frontiers of science and technology as a foundation for building a world-leading civilisation. The frequent invitations in the Qur'an to the use of sense observation, reflections on the Qur'an itself, as well as on the quest for truth and knowledge, combine to encourage scientific enquiry and experimentation.

'Science' is used in this article in the context of the natural sciences, such as physics, chemistry and biology. However, in contrast to its accustomed secular usage in the West, a Muslim scientist inspired by the Qur'an would maintain a connection of science with spirituality whilst acknowledging the world's divine origin. The Qur'an itself uses the term 'ilm, or knowledge in the broadest sense; not separating knowledge of the manifested world detected by the senses 
and rational thought ('alam al-shahadah), from the vastly greater world of the unseen ('alam al-ghayb), which transcends it. God encourages all to supplicate, "O my Lord, advance me in knowledge" (20:114). Many knowledge-seekers down the ages have also prayed as such, and have been rewarded with valuable insights. An American Nobel Prize-winning physicist, Charles Townes, in The Convergence of Science and Religion, elucidated that most important scientific discoveries appeared like a "revelation". This is akin to ilham, or divine inspiration.

God Almighty in His Wisdom provides humanity with two books - kitab al-tadwini (written revelation; i.e. al-Qur'an) and kitab al-takwini ('book' of natural phenomena to be deciphered ontologically). Interpretations of these two 'books' from the same Source should be in agreement. If they do not appear to be so then scientists need to revisit their theories since Muslims believe the Qur'an to be infallible. Muslim scientists have a great advantage over scientists of other faiths in that the Qur'an is believed to be pristine, i.e. extant in the original language of revelation, and without error. The Qur'an declares itself (2:2) to be a book of reliable guidance. So the Qur'anic verses on natural phenomena can yield true and reliable insights. The challenge however, is in interpreting meanings of the verses correctly.

Scholars believe that the Qur'an on its own admission contains references to all essential themes $(12: 111 ; 16: 89)$ but does not go into details. It is not a science textbook. However, it provides numerous scientific insights in more than 750 verses on natural phenomena.

Scientists should appreciate that Islamic scholars routinely derive insights and rulings from the Qur'an. Scholars of figh derive Shari'ah laws from it as the primary scriptural source using usul al-fiqh (jurisprudence) principles. Similarly, Muslim scientists need to approach and understand the Qur'an with taqwa (God-consciousness) and humility.

Informed tafsir (exegesis) of the Qur'an depends traditionally on four sources: the Qur'an explicating other verses, the Sunnah, Arabic language, and the Prophet's Companions. These should also be investigated regarding scientific exegesis of the Qur'an, called tafsir 'ilmiy. A number of classical polymath scholars applied a similar approach, including al-Jahiz (776-869) and Ibn Hazm (994-1064). The great classical Qur'an commentator, Fakhr al-Din al-Razi (1149-1209) was a pioneer using contemporary knowledge of science in his major work, Mafatib al-ghayb (The Keys to the Unknown). For example, from Allah's title, rabb al-'alamin (Lord of the worlds), in alFatihah, the opening chapter of al-Qur'an, he proposed the existence of many 'universes' rather than just the one known (the Milky Way galaxy) at the time. Only much later was the existence of other galaxies confirmed by Edwin Hubble 
using powerful telescopes in the early $20^{\text {th }}$ century. Rana Darjani, a Jordanian molecular biologist, believes that interpretations of the Qur'an can evolve with new scientific discoveries.

Arguably, among the most impressive Qur'anic verses, scientifically considered, are those describing development of the human foetus in the womb (32:8-9): "Then He fashioned him in due proportion, and breathed into him of His spirit. And He gave you (the faculties) of hearing and sight and feeling (heart)." These clearly prefigure more recent gynaecological findings of the true sequence of organ appearance in the developing foetus - first ears, then eyes, and finally heart.

As a young western scientist, my own experience in realising the Truth and so embracing Islam resulted partly from being shown Qur'anic verses accurately describing natural phenomena. My faith increased on reading the verse (21:30): "Do not the Unbelievers see that the heavens and earth were joined together, before we clove them asunder? ... Will they not then believe?" In 1967 as a university student learning about the origin of the universe, the "Steady State Theory" now considered obsolete, was still taught along with other theories. Only subsequently did the "Big Bang Theory" gain prominence and is still the most popular theory best fitting the available evidence. It is also the theory most compatible with what the Qur'an states regarding the universe's origin.

It is imperative however, that scientists do not over-stretch the meaning of verses to prove after the fact, that the Qur'an had pre-figured certain modern discoveries. Leading UAE scholar Nidhal Guessoum convincingly dissected and discounted some such claims from the Qur'an, e.g. determining the 'age of the universe and age of the earth'. Excessive claims using the so-called ' $i$ 'jaz (miracle) approach' may demean the Qur'an rather than reflect its inimitable qualities. Another error would result from being too adamant on adopting one Qur'anic meaning over other possible alternatives. One researcher, Fadhel alSa'd argued on television that the earth is flat, due to his faulty reading of verse 57:21. His view is easily disproved by observations from spacecraft.

The Muslim world would seem to be on the doorstep of important advances in scientific understanding inspired by the Qur'an. To enhance such development, the scientific fraternity needs support from governments and industry, and increased research funding. Close collaboration between the scholars of revelation (the 'ulama) and the scholars of natural phenomena ('scientists'), particularly by promoting development of those capable of crossing tadwini/ takwini boundaries in the pattern of the early Muslim universal scholars (likely reflected in the Qur'anic title, ulu al-albab - people of exceptional wisdom and sound intellect $)^{1}$, can recapture the initiative for a new Islamic enlightenment. 


\section{Notes}

* Daud AbdulFattah Batchelor, an Australian scholar, is Associate Fellow at IAIS Malaysia. He has a broad experience in industry, academia and international consulting covering the fields of Environmental Management, Islamic Political Science and Earth Sciences. He has been active in Muslim community organisations and is co-founder of the Islamic College of Brisbane. Daud has an MA in Islamic and Other Civilisations from ISTAC, and was presented the Longmans Award for $\mathrm{PhD}$ research at Universiti Malaya. He has an MSc from the Imperial College of Science and Technology, London and a Master of Engineering Science.

1. See Hassan, Mohd. Kamal (2010) A return to the Qur'anic paradigm of development and integrated knowledge: The Ulu al-Albab model. Intellectual Discourse, 18 (2). pp. 183-210 